\title{
City: Melting Locus and Cross-Cultural Difference Versus Rural (The Case of Tirana after the 90s)
}

\author{
Ana Rusta \\ French-Albanian School "Ernest Koliqi", \\ Tirana, Albania
}

Doi: 10.2478/ajis-2018-0037

\begin{abstract}
After the 1990s, with the recognition of a number of rights denied during the communist regime, such as free movement, there was a large movement of internal migration from rural areas to large urban areas, especially towards the city of Tirana. A number of factors, mainly economic and social factors, favored this massive population movement from rural areas to urban areas. Almost complete disintegration of the economic base in rural areas, as well as infrastructure shortages, have pushed large numbers of population into urban areas, especially towards the periphery, across migration flows. On the other hand, enormous rural migration not only redefined the physical boundaries of the city but also produced new social and economic forms. As a result of interaction and confrontation of the social and cultural mentalities between rural and urban population (the case of Tirana) emerged several phenomena that created a clear demarcation area under the cultural and social aspects, as well as semi-rural or semiurban hybrid interaction. In this perspective, this essay attempts to use a multidisciplinary approach to explain the general factors of this massive internal migration but also some aspects of the newly-formed landscape of social and cultural mentalities after this migration. As a result of this cultural interaction, we attempt to understand the reality of various subcultures in the city of Tirana and social behaviors in order to clarify the effects of this process regarding the dilemma on the ruralization of the urban or urbanization of the rural population.
\end{abstract}

Keywords: Internal migration, ruralization, urbanization, intercultural distinction, subculture

\section{Introduction}

The internal migration in Albania after the 1990s, mainly directed towards the prefecture of Tirana, is a very complex phenomenon because of the length of time, the various reasons that favored this migration, the typological traits that emerged as well as the new hybrid rural-urban forms that this process developed. In this essay, through theoretical literature, the use of statistical data of Instat, WB, UN as well as empirical studies conducted by Albanian and foreign scholars, there is a need to explain the dynamics, typologies of internal migration as well as to understand the nature of some psycho-cultural phenomena through the process of fusion between incoming and host residents in the prefecture of Tirana. By studying these phenomena as well as the special nature of the urbanization process it is required to prove the fact that in some respects there is the form of urban ruralization rather than a typical urbanization that is encountered in contemporary classical foreign literature.

\section{Several Socio-Economic Factors that Favored Internal Migration to the City}

According to classical literature, internal migration is caused by the interconnection of economic, 
social and cultural factors. However, although the case of Albania, and in particular of the city of Tirana respects these global theoretical considerations, it still shows a particular typology. The latter is characterized not only by the historical tradition of the Albanian population to migrate, but also by specific factors, which, reversed in the particularity of this process, receive new shapes, not typical of classical studies conclusions. Specifically, there are some classic reasons why this internal migration occurs.

First, after the collapse of the communist regime, some basic rights were legally recognized as was the case of free movement which constituted a favorable measure for internal migration. According to the law, it was stated that "Everyone has the right to choose his dwelling and to move freely around the territory of the country..." (Law on the major constitutional provisions, the Assembly of the Republic of Albania, 1993:166).

Second, this internal migration took the form of a movement that was seen as a challenge to the policies of the former communist regime. "Many villagers in rural areas wanted to enjoy a "forbidden fruit" for many years... Indeed, such moves were also motivated as a counterpoint to the politics of the communist state, which had controlled and hindered the free movement of people from villages towards cities" (Dervishi, 2001:33-42).

Third, prior to the 1990s, although conditions in Albania were generally bad, cultural and social living in rural areas was extremely difficult. Thus, "demotivated to live in the village, most of the villagers, especially the young, have aimed and aim to go to the city where they hope to provide a better lifestyle.... and more opportunities to experience it in a variety of entertainment, arts and sports activities" (Dervishi, 2001,1 (8):33-42). Further, given that in rural areas prevailed different prejudices, mainly young people, "...Want to be free from rumors of prejudice, to be more independent, not only from cultural traditions, but also from the sometimes annoying influences of relatives in their own lives" (Dervishi 2001,1 (8):33-42).

Fourth, many negative phenomena and psycho-social behavior of rural residents that existed prior to the installation of the communist regime began to be alive after its collapse. Mainly, the phenomenon of honour killings and blood-feuds has been noticed, mostly in remote mountainous areas in the north of the country.

Fifth and among the most important, bad economic, aggressive and rural infrastructure situation throughout the communist regime as well as the collapse of this economy after the fall of this regime created a massive wave of internal migration, projected over a period of more than 20 years with certain dynamics. More concretely "the main pushing factors of internal migration are linked to the economic situation especially to persisting poverty, low income prospects, poor access to public utilities, unemployment and insufficient agricultural land" (Carletto et al., 2006). Of all the cities, mainly Tirana, was the most attractive pole for these urban residents. The reason that pushes us to see as a factor of internal migration the economic factor does not simply come from a reading of classical literature in this field but also from the empirical studies carried out in relation to the city of Tirana. Mostly, the family migration dominated as a migratory typology and according to Carletto (Carletto et al., 2004, 7), family-based migration is conditioned by factors such as the beginning of a new job, the search for a better job, or the scarcity of land (Carletto et al., 2004). The other aspect that strengthened this fact is also related to the collective attitude of urban dwellers to collective or public property after the 1990s. Almost the bulk of collective economic structures such as farms and farm cooperatives were destroyed, robbed, or had a very low economic profitability, resulting in a collapse of the economic base. Further, unlike urban areas that benefited somewhat from the privatization process (recognition of real property rights to their real owners or their heirs or privatization of housing), in rural areas this had a poor impact. An important factor was the fact that the agricultural land often had a poor quality and the agrarian machinery was primitive. The other criterion was related to the new agrarian reform which also produced the phenomenon of fragmentation of agricultural land that significantly reduced economic viability. Empirically "the evidence to date suggests that those with limited access to land and other assets are more likely to migrate" (Kundu, 2003: 3079-87). Further, the interconnection of these factors invalidated the qualification and occupation of the farmer, increasing the level of unemployment and the poor economic situation of rural people. Historically, the profound impact of the economic factor on ruralurban migration is further strengthened by national studies, where there is a rising trend after the 
1990s, which culminates in the course of the '97s (the collapse of financial pyramid schemes) and to continue with the gradual downward trend, when conditions and the economy at national level improve (See Banka Botërore, 2007:34). Carletto finds out that "internal migration peaked during the period 1990-1993 and 1996-1998, as a reaction to tëo internal economic shocks, the drastic economic reforms and the collapse of the pyramidal schemes" (Carletto et al., 2004).

Sixth, "...The fact that the state has abandoned almost any role and the economic mission, especially in the field of agricultural production and livestock, is another factor that leads to the abandonment of mountainous hilly areas, economic depletion, ecological destruction, demographic breakdown as well as Cultural and educational drying of the poorest areas" ( Fuga, 2004:83). In this view, urban policies at the central level of government do not pay much attention to rural development in the country. PSo, "along with this process of liberty .... a second process happened in parallel, which has to do with the economic and social abandonment of rural areas by the political and economic actors living in cities.... The village gained decision-making autonomy by paying it with the abandonment of the city. The city does not feel almost any obligation to give its former technical, economic, financial, health, cultural assistance to rural areas" (Fuga, 2004: 132-133)

\section{The Dynamics of Internal Migration}

The dynamics of internal migration from the other prefectures to that of Tirana are complex as they have been influenced by various factors and have been extended over a long period of almost 20 years. However, we may notice some tendencies and we can understand some of the regularities in this chaotic internal migration movement.

First, over 20 years, there is an increase in internal migration to the Tirana area. Initially, this led to a radical change in urban population ratio to the total populationin the prefecture of Tirana by about $70.2 \%$, which is not explained by the increase in the natural birth rate (Instat, 2011:162).

Second, we notice that the pace of the total number of migration to the Tirana area increases steadily after the $90 \mathrm{~s}$, and culminates in the $97 \mathrm{~s}$ with the collapse of pyramid financial schemes, which underlines the fact that the economic factor becomes the main catalyst of this the pace of migration. The official census regarding the population registration of the Tirana district in 2001 marks 368,000 in 1989 to 520,000 in 2001 (Instat, 2002).

Third, the various internal migration movements towards the prefecture of Tirana are mainly characterized by a family migration. According to Instat (Instat, 2011) regarding Indicators of population by prefecture, Tirana has the youngest senior age (except for the Kukes prefecture), which implies that migration has taken place from families with many children and who are relatively young in age.

Fourth, in the internal movements towards Tirana from 1990-2005, most of them are from north and northeast of Albania, more precisely 39 percent from Kukës and 34 percent came from Dibër (Instat 2014:15). Meanwhile, generally internal movers coming from southern prefecture $u$ vendosën në zonën e Kashar dhe Farkë, internal movers from northern prefectures are mainly concentrated in Kamza and Paskuqan (Instat, 2014:16). Further, the study of Instat notes that $96 \%$ percent of movements to Tirana came from a different prefecture (Instat 2014: 24).

\section{Typology of Internal Migration}

Tipology of internal migration over the 20 years towards the city of Tirana shows some movement patterns: From rural to urban areas, from mountainous areas to flat and coastal areas, from north and south to center (Tirana, Durrës), from home to abroad. Firstly, with regard to this recent movement, empirical studies prove that there is simultaneous migration from rural to urban and migration abroad. It is believed that the latter has always been a source of revenue to support and facilitate the realization of a successful internal migration to urban areas targeted. Mainly, "remittances from abroad have been crucial in financing an internal move of the residual family in Albania" (Vullnetari, 2012). Further, this internal migration shows the dynamics of two opposing movements. Initially, it is seen as a first step to further project migration abroad, and then the new settlement chosen by internal migration to the city serves as a return location for migrants returning 
from abroad. So there is a circular migration, showing a more frequent dynamics in cases when immigrants migrate abroad for short-lived periods. In this phenomenon, it is noticed the form of an "accumulative migration which emphasizes a difference between migration for survival and migration for additional income" (Deshingkar and Start, 2003). Here is the emphasis on the economic role of remittances as regular flows to support livelihoods in the new urban settlement by rural residents as a key strategy. Thus, "the overall increases in circular and temporary migration suggest that migration is part of wider household strategies that involve multi-activity-including farm and non-farm income sources-over multiple locations. Migrants contribute to their households' welfare and return on a regular basis" (UN, 2011:113)

Secondly, it is emphasized that the typology of internal migration towards the city of Tirana is influenced by the creation of new settlements on a provincial basis, city or village from which they originated. According to Instat's studies related to this, it is noted that residents coming from the south are mainly located in the area of Kashar, Farkë, Kodra e Priftit and those coming from the northern area are mainly located on Kamëz, Paskuqan, Bathore etc. (Instat, 2014). Indeed, in certain areas within these territories, they have been outlined with a kind of regularity creating whole neighborhoods on the basis of blood-line relations and wider kin. In this sense, it seems that these residents have transposed into the host area the same typology of rural areas.

Third, the family-based internal migration reinforces the notion of strong ties and the example of a nucleic family, although with many members. "Today's Albanian citizen residing in the rural or urban area of the country is more connected to his family group than to social realities that make up the most remote suburbs of his socialization, such as the state, the nation or the village, political organizations, professional solidarity, etc." (Fuga, 2004: 271). Further, this migratory typology also represents the fact that the family of internal migrants coming mainly from the country's deep rural areas is dominated by patriotic connections. "Family is a very strong institutional structure in Albania, and one which usually occupies a very important place in the migration process" (Hall 1994: 83-84). On the other hand, this cultural mentality seems to better enable internal migration and living in host areas, as there is a shared family strategy with separate roles." In almost all cases, the person receiving the remittances and administering the whole of the family budget is the male head of the family. As within any patriarchal setting, women usually have an important function in the management of the material life of the household, but do not take part in the decision-making" (King and Vullnetari, 2003:19).

Fourthly, internal migration to the city is manifested in different phases as regards the individual and family migration of rural residents towards the city. Specifically, their migration is carried out in two phases where, in the first phase, the oldest and juvenile members of the family are still in the village and in the second phase, young people migrate towards the city, where, after the consolidation of the financial situation, they draw away all the family members. Thus, their basic function is to provide the economic and financial backgrounds of the rural household and to generate additional income that initially enables the survival of family members who have already left their homes to go to cities as the forerunner of the exodus of the rural family. Especially in the first phase they need financial support. By contrast, those who fled first are mainly young, thirty or forty years old couples, mature men" ( Fuga, 2004:159). people.

Fifthly, the influx of internal migration to the city (mainly to Tirana) is dominated by young

More than 50 percent of migrants that have changed their town or village of residence were aged between 15 and 34 year old, with a distinct peak at the age of 20 to 24 where family reasons are the main reason for migration for both men and women (Instat 2014: 25).

Sixth, Instat's (Instat 2014) studies on internal migration in the relationship between man and women show a dominance of the latter (59 percent of internal migrants being women) which creates the typology of a feminization of migration. The reasons for women's migration are diverse, including economic and non-economic factors as the opportunity to escape social control or gender discrimination. In fact, the numerical dominance of women appears mainly at younger ages; it is devoted to several factors such as "the purpose of marriage and founding a family (patrilocality)... because they do not have access to family heritage (farms)" (Instat 2014:25) 


\section{Positive Perception and Bitter Realism Regarding the City}

The idea of a positive projection about the perception of the city of Tirana by the incoming residents (mainly from the remote rural areas) was related to the difficult economic and cultural conditions of living in the country of origin. Thus, the idea of migration was seen as a compensatory and complementary focus of the conditions they could not realize in their country of origin. Generally, and not without realism, there was in their minds the idea that "urban life presents immensely important material benefits compared to rural life: health services, cultural centers, health, social life, power supply, drinking water" (Fuga, 2004: 159). Meanwhile, the concretization of this perception led to several phenomena.

First, in the psycho-cultural aspect there was a kind of "contact hygiene" between the incoming and host residents. Especially the oldest autochthonous residents who had lived in Tirana for many generations have been more conservative about social and cultural relations with residents coming after the $90 \mathrm{~s}$.. For example, they show a conservative attitude towards possible marriage ties with those residents. After the 1990s, a general stigmatization of indigenous residents against those incoming residents (especially from the North). Meanwhile there is a kind of "contact hygiene" even among the incoming residents themselves on the basis of provincial or cultural origin. The fact that these incoming residents have formed whole neighborhoods on the basis of provincial or prefecture origin is proof of this fact where each one wants to support and coexist with the same. Further, this large urban density caused by the great wave of internal migration produced a large mosaic of subcultures and behaviors that led to an increase in deviant phenomena and a tension between urban and rural residents. According to sociologist Dervishi "... the rise of crime in the city and village over the last 7-8 years has generated mutual mistrust and suspicion that in one way or another removes citizens from villagers" (Dervishi, 2001:33-42).

Second, "this population concentration has not been accompanied, let alone guided, by forward looking policy action.... Examples abound with regards to overpopulation of public schools in the city, and only few schools in peri-urban areas; dire lack of public health centres outside key city centres..." (Vullnetari, 2014: 47-67). Furhtermore, as Zelinsky points out “... even when migration is accumulative the costs of migration remain high" (Zelinsky, 1971: 219-249).

Third, This phenomenon of migration of rural residents under the conditions of a new dynamic of the labor market typology in the city brought about the loss of the close relationship that existed between the family and the land, causing women to either work housework or work in sectors that did not require a high qualification. Meanwhile, the men again, having lost their relationship with the land, began to carry out heavy physical labor mainly in craftsmanship and construction. Initially, this inadequacy of the professional skills of working rural inhabitants influenced the creation and strengthening of the informal economy sector. Thus, "the informal sector is the main entry point into the urban economy for migrant families in Tirana as its labour market provides sufficient opportunities" (Gedeshi and Jorgoni, 2012).

Fourth, the high rhythm of the informal sector in the economy subsequently created the overurbanization phenomenon predicted by the Hozelits theory (1957). Consequently, "migrants supply far more labour than the formal sector can absorb and labour is absorbed into the informal sector which then leads to low productivity and limited prospects for exiting poverty"(Hoselitz, 1957). This overwhelming economic situation prevalent on the incoming residents created pockets of poverty, mainly in peripheral areas of the city, creating a " re-location of poverty from the rural north to periurban Tirana" (Zezza et al, 2005: 175-93). All of this situation produced a domino effect with regard to the negative impact on everyone in Tirana. Further, this attitude of the incoming residents to the infrastructure that the city offered was also reinforced by the fact that it made it impossible or too financially to carry out public projects for the urbanization of these areas with the entire necessary infrastructure (see (UN, 2011:10). However, these effects did not have the same impact on rural residents as "time is a crucial factor in increasing well-being, as those who have settled are more likely to have better jobs and living conditions, compared to recent arrivals who are poorer and live in more precarious situations" (Vullnetari, 2014: 47-67 ).

Fifth, it should be noted that coping these negative phenomena by the incoming residents, mainly from remote mountainous areas, has not been the same. Through the 20 -year migration, the 
nature of the labor market in the city as well as the way of their integration has undergone some flexibility. Thus, migration of these residents also changed the nature of the labor market in the city and the new opportunities it offered. Generally, after the years 2004 "among this population, there are social groups that come to the city for various reasons, following their life history. There are individuals and social groups that envision the city as a kind of attractive poly-cultural attraction. There are others who take the road that leads to the city, aiming to realize their professional integration there" (Fuga, 2004:168). Specifically, the high unemployment rate prevalent in the city of Tirana for indigenous residents as well as the reasons did not always resemble those of the incoming residents. Thus, " it is not excluded that local citizens are left out of work and newcomers from the village are employed. Often, this is related to the fact that newcomers accept to engage in crafts that are morally admitted with difficulty by the indigenous urban population" (Fuga, 2004:169)

Sixth, mainly in internal migration after the 2000s, due to the changing labor market dynamics in cities and the type of urban economy, also changed the factor motivating residents to migrate towards the city of Tirana. Fuga considers that, under these conditions, cultural factors become the premise for this kind of migration. He emphasizes that "....Man today does not go to the cities simply to find a job whatever (moreover, not all villagers are driven out of their land), but to find a "urban" type job... The return path is almost closed to them, not so much for economic reasons as for mental reasons..... And when the economy operates within a single one, it means that it first obeys cultural factors..." Fuga, 2004:165). With the changed conditions and requirements of the urban economy, more and more demand for services rather than physical labor began to emerge, enabling incoming residents to structure their labor supply. Thus, "...Today are losing their place in the fast-paced society of industry-related crafts that leave their place to the new urban servicerelated professions.. Residents of rural areas who have just arrived in the cities can be employed mainly as guardians of houses, public buildings, private police, small ambulant traders, van drivers..." (Fuga, 2004:161)

\section{Transplanting and Designing the Mentalities and Social Forms of Internal Migrants}

After the 90s, naturally Albanians began to appreciate more and more the material values against the spiritual ones. Economic wealth as well as its fruits, being always impossible to enjoy during the communist regime, constituted the main impetus for migration inside and outside the country. On the other hand, it should be mentioned that internal and mainly external migration not only brings economic capital but also social and cultural capital. According to the new economics of migration theory by Stark and Bloom (1985) "migration creates new forms of social capital, both in the destination and across space (multi-spatial)" (Stark and Bloom, 1985:173-178). Studiues të tjerë si Levitt (1998) Other scholars like Levitt use the term 'social remittances' to emphasize the dissemination and melting of cultural patterns of behavior, attitudes from communities where they have lived or from where they have immigrated abroad (see Levitt,1998:926-48.). Later on, these effects created exactly in the urban panorama of the city of Tirana two different dynamics. First, a panorama of cultural and material elements was created between the incoming and the host population. Thus, "the rapid growth of the population has been accompanied not only by an urban focus but also by the increased presence of rural elements, of rural lifestyle and mentalities... Most of those residents live physically in Tirana but mentally they belong to the subcultures of the areas they came from ... the suburbs of Tirana has the appearance of a large village." (Dervishi, 2001:3342). Empirically, census statistics in 2011 prove this transposition of the material mentality of the lives of residents who came to Tirana. Regarding the type of building for residential purpose, no. of apartments in the building, no. of floors in the building, we conclude that out of 110,283 residential buildings in Tirana prefecture only 6994 are flats, while the rest constitute detached, semi-detached or row house. In this case, this fact is not only the transfer of the way of living in Tirana to the same as that of the country of origin, but also the reason that this was favored by the inability to buy an apartment as well as cheaply constructed or illegally owned land. Thus, "Cultural diversity is also expressed ... in material culture, in interior furnishing and especially in the exterior architectural appearance of dwellings" (Dervishi, 2001:33-42). Meanwhile, in the cultural aspect, the city of Tirana constitutes an oasis where for the first time psycho-cultural mentality emerged that did not exist in indigenous urban dwellers. After the 1990s, a series of negative phenomena began to 
emerge in the country's deep mountainous areas, especially in the north, such as honour killings and blood-feuds. Thus, if we thoroughly analyze these cultural and material traits created following the migration of the inhabitants, mainly rural to the prefecture of Tirana, we notice that in general there is a ruralization of urban areas.

\section{Conclusions}

Based on statistics and numerous studies of domestic and foreign researchers regarding the phenomenon of internal migration, in the case of Albania it was understood that it is a very complex phenomenon and that differs in typology from the same processes occurring in the West or in Eastern countries after the 90s. Basically, domestic migration in the case of Albania happened in a chaotic and unsupported way from the deep urbanization process, creating poverty pockets, mostly on the periphery. There were often several psycho-cultural traits in the migratory population, along with the economic factor, that determined the typology of this process based on the patriarchal family, the creation of new settlements on a provincial basis, the migration mainly from young people and the accompaniment of this internal migration process from external migration. These typologies and this great density of inhabitants with different subcultures created in the Tirana area not only negative phenomena but also cultural mentality, foreign to the host population, which in contact with the latter shaped semi-rural and semi-urban hybrids.

\section{References}

"Ligji për dispozitat kryesore kushtetuese", Kuvendi i Shqipërisë, 1993:166

Banka Botërore (2007), "Shqipëria:Zhvillimi Urban, Migrimi dhe Ulja e Varfërisë, Një Vlerësim mbi Varfërinë", 19 qershor.

Carletto, C., Benjamin, D., Marco, S., Stefano, T., Alberto, Z., (2004), "Internal mobility and international migration in Albania", ESA Working Paper No. 04-13 04, no. 13

Carletto, G., Davis, B. Stampini, M., Zezza, A. (2006), "A Country on the Move:International Migration in the Post-Communist Albania" in International Migration Review, Volume 40/4, pp. 767-785.

Dervishi, Z. (2001),"Urbanizimi i jetës së popullësisë fshatare apo ruralizimi i qytetarëve? Rasti i Tiranës", Politika dhe Shoqëria,1 (8): 33-42

Deshingkar, P., and Start D. (2003), Seasonal Migration For Livelihoods, Coping, Accumulation And Exclusion, Working Paper No. 220, Overseas Development Institute, London).

Fuga, A. (2004), Shoqëria periferike, Ora Botime

Gedeshi, I., Jorgoni E. (2012), "Social Impact of Emigration and Rural-Urban Migration" in Central and Eastern Europe, Final Country Report Albania

Hoselitz, B. (1957), "Urbanisation and economic growth in Asia", Economic Development and Cultural Change, $6(1)$.

Instat (2002), The Population of Albania in 2001: Main Results of the Population and Housing Census. Tirana: Instituti i Statistikës.

Instat (2011), Population and Housing Census.

Instat (2014), Migration in Albania.

King, R. and Vullnetari, J. (2003), Migration and Development in Albania, Brighton: University of Sussex, Development Research Centre on Migration, Globalisation and Poverty, Working Paper C5.

Kundu, A. (2003), "Urbanisation and urban governance: search for a perspective beyond neoliberalism", EPW XXXVIII(29): 3079-87, 19 July

Levitt, P. (1998), "Social remittances: migration driven local-level forms of cultural diffusion", International Migration Review, 32(4): 926-48.

Stark, O. and Bloom, D. E. (1985), "The New Economics of Labor Migration", American Economic Review 75:173-178.

United Nations (2011), Population Distribution, Urbanization, Internal Migration and Development: An International Perspective.

Vullnetari, J. (2014), Internal migration in Albania: A critical overview, in Pichler, R. (ed.) Legacy and Change: Albanian Transformation from Multidisciplinary Perspectives. Vienna: LIT Verlag, vol. 15 of series Studies on South East Europe, Kaser, K. (ed.), 47-67.

Zelinsky, W., (1971), "The Hypothesis of the Mobility Transition", Geographical Review , Vol. 61, No. 2

Zezza, Alberto, Gero Carletto and Benjamin Davis (2005), "Moving Away from Poverty: A Spatial Analysis of Poverty and Migration in Albania", Journal of Southern Europe and the Balkans 7: 175-93. 